Cover page of manuscript

Learning for Being: an ontological and existential approach By:

Helen Russell

Faculty of Education,

Charles Sturt University,

Wagga Wagga NSW 2650

AUSTRALIA

Phone: 61269334098

Fax: 61269332888

Email: hrussell@csu.edu.au 


\section{Author's bionote}

Dr Helen Russell is a Lecturer in Information Technology in the Faculty of Education at Charles Sturt University, Locked Bag 588, Wagga Wagga, NSW, 2678 Australia. 


\title{
Learning for Being: an ontological and existential approach
}

\author{
HELEN RUSSELL \\ Charles Sturt University, Wagga Wagga, NSW 2650, Australia
}

\begin{abstract}
Author's bionote
Dr Helen Russell is a Lecturer in Information Technology in the Faculty of Education at Charles Sturt University, Locked Bag 588, Wagga Wagga, NSW, 2678 Australia.
\end{abstract}

\begin{abstract}
This paper will investigate the ontological and existential learning experience of a group of laterlife computer learners in Sydney, Australia. The research, undertaken as a $\mathrm{PhD}$ project, focused on the interpretation and understanding of the learning experience from the perspective of the learners. Hence, a qualitative method was used because it enabled existential insights into the learning experience and privileged the voices of the participants. A hermeneutic phenomenological method was considered suitable because of its emphasis on understanding the lived experience of people. The research found that participants wholeheartedly believed in the worth of the learning they were undertaking. They felt that the outcomes from learning would lead to
\end{abstract}


greater opportunity for participation in their lifeworld. Without computer skills and knowledge they believed they would be ignored and relegated to a peripheral position as observers in their lifeworld. Their purposes and expectations in undertaking learning were situated in the changing nature of the world and a desire to continue to live their lives authentically, as participants and not spectators. Learning for the people in the study provoked both ontological and existential questions that demanded answers. The author believes that the findings from this particular research could be used to inform other studies involving both adult learners and lifelong learning.

\section{Learning and Being}

The purpose of this paper is to explore the notion that adult learners experience the ontological and existential aspects of learning as a significant part of the affective epistemology. In this section, Learning and Being, I will focus on adult learners' search for ontological and existential meaning that not only influences the self as self (I) but also the self as learner in an ontological dyad (I-learner). Jarvis (2006: 3) positions learning as 'essential to humanity' and 'a fundamental stimulus for life itself'. The close association of learning with the self fosters ontological and existential questions that are both reflexive (reflections of the self) and critical (influential within the experience). Dewey's (1933: 9) widely used definition of reflection helps to elucidate meaning. 'Reflection is the active, persistent and careful consideration of any belief or supposed form of knowledge in the light of the grounds that support it and the further conclusion to which it tends'. This ongoing reflection is shown by many researchers to be a crucial part of adult learning (Cell 1984, Kolb 
1984, Boud, Keough and Walker 1985, Mezirow 1991, Brookfield 2000, Jarvis 2006). Learners potentially devise answers that help shape the experience and influence important milestones. The answers may be particularly relevant for the construction of self-efficacy and confidence as well as the belief in their ability to achieve and learn, and hence, to keep on learning.

The inexplicable link of learning with life is explored by both Fromm (1947) and Jarvis $(2004,2005,2006)$ in their extensive research and reflection about the meaning of life and learning. They believe that human existence is in a state of constant and unavoidable disequilibrium. Experiencing this state 'forces the Being into becoming the eternal wanderer, impelled to go forward with everlasting effort to make the unknown known' (Fromm: 41). When the Being is not in harmony with the world it is in a state of disjuncture and uneasiness and this leads to the quest to change and to find new solutions in order to achieve equilibrium (Jarvis). The 'insoluble dichotomy of human life is inescapable' and can only be solved by each Being 'striving to alleviate the disquiet within and to create a lifeworld in which there is satisfaction and harmony' (Fromm: 40). The dichotomy is rooted in the very Being and therefore constitutes an 'existential dichotomy' (Fromm: 41). This means that the Being can react to the 'insoluble dichotomy' in various ways according to culture and the individual.

As in all human endeavours there are elements of disappointment and struggle but also excitement and wonderment. Fromm (1947: 41) refers to the eternal wanderer who 'constantly searches for the answers to fill in the blank spaces of knowledge'. The eternal wanderer analogy evokes the fictional characters in Alice in Wonderland, Don Quixote, Gulliver's Travels, Ulysses and The Old Man and the Sea. Fromm's description of the eternal wanderer conjures up images of people on the move, 
constantly faced with adventures and challenges. These voyages of discovery and striving for answers are creative learning ventures that encompass uncertainty, risk and possible danger. The adventure solution to the 'insoluble dichotomy' of the Being may not be possible for most people; however, learning is possible and according to Jarvis $(2004,2005,2006)$ the solution to the dichotomy lies in learning. This concept therefore locates learning as a human endeavour.

Similarly to Fromm's (1947) disequilibrium and Jarvis's (2004, 2005, 2006) disjuncture, many other authors refer to the impetus or the event that precedes learning. Dewey (1964) advances the argument that learning is precipitated by desire, an emotional reaction to the present state of things. Inherent in the concept of desire for learning lies the notion of an unsettling feeling that something is not quite right. In Dewey's terms, when things are going along smoothly desires do not arise, and 'without the desire to learn there is no need for the effort and struggle involved in learning' (1964: 87). Other authors offer conceptually related views on the impetus for learning. Tough (1979) identifies trigger events as the springboard for adults engaging in learning. In transformative learning adults are confronted with a disorienting dilemma that precedes the learning (Mezirow 1991). The confronting instances are not necessarily single events. They may occur over time and not be significant in and by themselves but collectively have the same effect as one trigger event (Tough, Mezirow 2000a). Critical personal experiences suggest that the Being is faced with having to make choices and that ontological and existential questions will be posed. The Being is forced to stand back and consider what the event means and how to respond to it. The literature suggests there is a period of reflection after the unexpected event in which an attempt is made to understand the dilemma and seek 
to lessen the discomfort by 'doing something about it' (Brookfield 2000, Mezirow 2000a, Jarvis 2001a).

Jarvis (2001a) believes that disjuncture leads to the potential for learning and that the prospect of learning is exciting. However, there is a paradox or contradiction in the search to relieve the disjuncture (Fromm 1947, Jarvis 2004, 2005, 2006). In order to feel a sense of equilibrium there is a necessary period of disequilibrium. Eliot suggests this is akin to agony. In order to attain knowledge the Being has to go via a place of no learning.

To arrive where you are, to get from where you are not,

You must go by a way wherein there is no ecstasy.

In order to arrive at what you do not know

You must go by a way which is the way of ignorance.

T. S. Eliot

East Coker

The path of 'no ecstasy' as described by Eliot may not necessarily deter the Being from learning. When the Being truly examines the self and balances the consequences of no-learning versus the outcomes of learning they will choose the sometimes painful but ultimately rewarding, path of growth (Rogers 1951). This seems to suggest that human endeavours are intrinsic to growth and development, and to the Being.

Learning forces the Being into a continual reflexive state that is 'ontologically and existentially directed' (Kidd 1973b: 5). The ontological questions raised by Kidd's notions are: 'Who am I? What do I want for myself? Where am I going? How will I get there? When will I get there? Where do I belong?' According to Kidd 
(1973b: 9) learning is about self-discovery, self-expression and fulfilment, and involves a search for that part of the Being that is truly human. In a similar notion to Allport's (1955) belief that the more we know about the self the more we know about the whole human race, Rogers (1969) asserts that the deeper the Being delves into the self to find the unique, the more the Being finds the whole human race. Kidd believes that this insight is not enough and that as humans the relationship factor makes learning meaningful. Kidd's triad of Being-becoming-belonging is situated in the ontological and future-directed nature of learning. As a Being we are always becoming, not in a selfish pursuit, but striving towards individual and social goals (Kidd). Without the belonging component, Being-becoming would remain individually-located and self-centred and Kidd believes belonging is what gives learning its real meaning. Frankl illuminates this aspect of the Being when he refers to the location of the true meaning of life as outside the Being. 'The true meaning of life is to be discovered in the world rather than within man or his own psyche as tho it were a closed system' (1985: 133). The importance of Kidd's belonging element to the Being-becoming dualism is augmented by Frankl (1985: 133) who states that 'being human always points, and is directed, to something, or some-one, other than oneself'.

Two contrary forces lie at the heart of becoming, the personal and the tribal, and humans seek to reconcile these in the struggle of learning (Allport 1955). The personal force involves the need for autonomy and independence and the tribal force involves the need to make meaningful connections with other people, to reach out to other humans. Kidd cites Maslow as later recognising the social element in Maslow's (1962) self-actualisation model. Kidd extends Maslow's Being-becoming combination by including the belonging element to complete the triad. The third 
element in the triad is included because of Kidd's notion that belonging is in human relations, both to others and with others. 'Learning to be, learning to become and learning to belong, involve human need and human potentialities in a celebration, affirmation and enlargement of full consciousness' (Kidd 1973b: 4). In Kidd's (1973b: 10) model of learning, Being-becoming-belonging is about 'living; growing, enlarging and evolving in a life that encompasses others'. Jarvis also refers to the Being-becoming-belonging nature of adult learning. 'Learning is about becoming a person in society, about transforming the experiences of living into knowledge, skills and attitude so that human individuality might develop' (Jarvis 1992: 237).

Experience of any kind is a series of intentional acts, in which the experiencer is directed toward an intentional object beyond itself (Stanage 1987: 186-189). Each experience may overlap another experience of the same object, and disclose possibilities of other experiences beyond itself. Stanage's concept of looking beyond a specific experience implies a future aspect, to something in the distance and not exclusively limited to one experience at that one time. Other writers also mention the future-relationship with learning, learning and living for the future; a future that encompasses others (Kidd 1973b, Beatty and Wolf, 1996). In Kidd's terms it is learning to belong, for Beatty and Wolf it is in actively constructing the future. The literature implies that learners look past the specific learning event to a place and time in the future; a place they want to be. It suggests learners learn their lives into the future.

The previously discussed notions of Being-belonging-becoming (Kidd 1973b) and self-actualisation (Maslow 1970) contribute to an understanding of the outcomes of learning and how individual learners interpret the experience. The idea that learning always has satisfactory outcomes for learners is dispelled by Day (1988) who 
states that learning has consequences, and the results of learning may as likely lead to discontent as to a state of wellbeing. All learning involves change and significant learning can be painful, distressing and turbulent because it threatens the sense of self and involves giving up some previous learning (Rogers 1969). Mezirow (2000b) also claims that with transformational learning there may be painful and confronting outcomes that threaten the sense of self. Mezirow's transformational learning theory is grounded in the ability of learners to be self-directed and critically reflective. A transformation can be different to an effect or an outcome and not all learning will necessarily involve a transformation. Mezirow believes the potential for transformational learning takes place with a combination of factors. These include: trigger events or disorienting experiences that can be sudden or occur over time, critical reflection, engagement with other people for the purposes of confirmation and affirmation, and a change in perspective, i.e. a whole new way of looking at something that involves taking action.

The very nature of learning means that there is uncertainty about outcomes and that learning involves risk and challenge but it also includes potential excitement and innovation (Jarvis 2001a). There is general agreement that the process of learning is dynamic, iterative and can be complex and perplexing, moving between the private and the public spheres (Dewey 1933, Kidd 1973b, Jarvis 2004, 2005, 2006, Mezirow 2000b). A characteristic of the lifeworld is that it can be chaotic and orderly at the same time and can support ambiguity, frustration, tension and affirmation; in much the same way as in learning. 'The paradoxes of learning are situated within the human experience and the paradox of the human condition' (Jarvis 1992: xi). Learning can contain contradictory elements that are troubling and yet enticing (Brookfield 2000). 
Learning can be whatever learners make of it. Keating and MacLean (1988) refer to the essential relationships between the context, the process and the outcome that make up the meaning of the learning experience for the individual. Therefore each person's experience of learning will be different from another person's experience as well as different from their own other learning experiences. The experience is what the experiencer says it is and the meaning is in how the experiencer chooses to reconstitute the interactions between the Being and the environment. 'Individual experience refers to the subjective consciousness of current events' (Jarvis 2001a: 47). Van Manen's (1997) notion that experience implicates the totality of life accords with Jarvis and further supports the view that the socio-cultural context is vital to an understanding of the lived experience of adult learners. Investigating the socio-cultural context of adult learning is beyond the scope of this paper but is acknowledged as an essential element in the ontological and existential meaning of learning for adults.

The literature as outlined previously in this section positions itself within the affective domain of adult learning. With this in mind it seems reasonable to assume that the affective domain is significant and relevant to the experience of learning for adults. The affective domain, which includes emotions, feelings, values, attitudes and senses, is important in all studies of adult learning and more attention should be paid to it (Brookfield 2000). Learning is believed to be a fusion of the intellectual and emotional, of meaning and value, an emotive process as well as a cognitive process (Dewey 1933, Brookfield). It is because of the human nature of learning, the paradoxes of learning, that adults are faced with complexity, contradictions, ambiguities, and pleasure and pain (Jarvis 1992, Brookfield). 
The literature as described in this Learning and Being section, relating to the ontological and existential aspects of learning, has shown that adults face Being disjuncture that can only be resolved by learning and seeking meaning. However, I have also shown that some authors believe that learning will not necessarily lead to pleasant outcomes and that the Being may in fact be faced with further disjuncture and discomfort, beyond the specific learning encounter. The literature contributes to an understanding of the lived experience of adult learners by reaching into the very essence of life and asking deep questions about the meaning of an individual life. In this paper I have used the literature from the Learning and Being to inform my understandings and interpretations of the data from my $\mathrm{PhD}$ research project. I acknowledge that the interpretations are located in the area of laterlife learning and this may be significant. However, I propose that the ontological and existential framework can be equally applied to other adult learning contexts.

\section{Background to a study of laterlife computer learners}

I interviewed nineteen participants in 2003 and 2004 as part of a $\mathrm{PhD}$ research project. The process of finding people willing and suitable to be a part of my study began by identifying local, state and national organisations with members over the age of 60 years. These included Seniors Clubs, Retired Associations, the New South Wales Council Of The Ageing, the Older Women's Network and the Australian Seniors Computer Clubs Association. I wrote to the organisations requesting the distribution of information regarding the research project. Most of the organisations published the information in their newsletters. I was subsequently contacted by people 
interested in being a part of the research. During the initial discussion with potential participants I was able to consider their suitability for inclusion in the study. In bounding the case for the study I included people who identified as beginning computer learners, had not used a computer in their working lives, were attending computer classes for the first time and were not computer tutors within the organisation. Their learning situations were within the non-formal learning environment description provided by Jarvis as 'any form of systematic learning conducted outside of a formal organization' (2001a: 21-22). All participants either paid nothing or a minimal amount to attend and receive lessons.

Participants were not currently engaged in or seeking paid work and they identified themselves as being retired. Their previous professions were varied, including accountant, dressmaker, nurse, stenographer, teacher, technician and telephonist. Their ages ranged from 63-86. Only one participant had a non-English speaking background and was not born in Australia. The other participants were born and raised in Australia, with English as their first language. All people lived in Sydney, Australia.

The development of the interview schedule and the influences on the framework for the interview schedule were underpinned by the three research questions.

1. What is the nature of the learning experience of laterlife computer learners?

2. What interpretations do laterlife computer learners place on their learning experience?

3. What are the outcomes of the learning experience of laterlife computer learners? 
In developing the interview schedule I was also guided by significant authors from the thesis literature review.

The first influence from the literature comes from five dimensions of the nature of the learning experience. These dimensions were identified as: affective, conative, cognitive, manual dexterity and social. Questions in relation to these five dimensions form the core of the interview schedule. Dimensions are believed to influence the way learners construe experience (Mezirow 2000a, 2000b). I considered the inclusion of the five dimensions to be essential because they contributed to answering all three research questions. Examples from the interview schedule that relate to uncovering the nature of the experience are the following two questions.

1. Before you started computer lessons what things [for example skills, aptitude, knowledge, attitude] did you think would be important to learning how to use a computer?

2. Did you think you had those things?

The second influence on the development of the interview schedule comes from the notion that learning in adulthood is complex. Theorists variously describe learning as dynamic, complex, perplexing, non-linear and iterative and this has been described previously in the section 'Learning and Being'. In Kidd's (1973b) model of learning the three elements of Being-becoming-belonging are inseparable. I was also influenced by the paradoxes of learning (Eliot 1969, Fromm 1947, Jarvis 1992, 2001b, 2006) and how they may apply to the unique perspective of older adult computer learners. Examples from the interview schedule that relate to uncovering the complexity of the experience are the following four questions. 
1. During your learning have you experienced any highs?

2. Did you share these experiences with anyone?

3. During your learning have you experienced any lows?

4. Did you share these experiences with anyone?

The final influence on the development of the interview schedule comes from the need to answer the third research question, the outcomes of the learning experience. Outcomes as perceived by learners were considered from the two perspectives of individual and societal. I was influenced by the literature that relates to the approaches learners take to their learning, their purposes and intent (Beatty and Wolf 1996, Moody 1976, Sherron and Lumsden 1990, Thorson 2000). In the context of older adults who have a heightened sense of time I was also influenced by existential and ontological questions. Examples from the interview schedule that assisted in uncovering the individual and societal outcomes of the experience are the following four questions.

1. What do you enjoy most about the lessons?

2. What impact has learning how to use a computer had on your life?

3. Apart from learning the computer did you hope to achieve anything else?

4. What part do you think age plays in your learning experience?

These example questions are taken from the interview schedule and represent the link between the intent of the research, the research questions and the 
methodology. This is explored at length in the thesis which also includes a complete interview schedule (Russell, 2005).

In determining a method for the study I was guided by both the intent of the research, to interpret the lived experience from the perspective of the learners, and my interest in understanding the lived experience of laterlife computer learners. An underlying influence came from the research questions described previously in this section. The three research questions called for a sympathetic human science methodology that would foster critical reflection, encourage and support a focus on human experience, and allow for the complexities, dimensions and dynamic nature of lived experience. Van Manen suggests that the method is determined by the research questions and the researcher's understanding of the questions (1997). Van Manen does not mean that research questions are framed without knowledge of a suitable method to investigate the questions. Rather, he believes there exists a 'certain dialectic between research questions and method' and that 'the choice of methodology should not only be driven by the dialectic, but should be in harmony with the researcher's own deep interest in the field of study' (1997: 2). Hence, a hermeneutic phenomenological method was chosen because it enabled rich existential and ontological insights into the learning experience and privileged the voices of the participants.

My understandings of phenomenology and hermeneutics were influenced by the work of Heidegger (1962) and his ontological 'account of the human-world relations which determine and outline the dimensions of human existence (Dasein)' (Ihde 1990: 23). Heidegger's link with ontology influenced my orientation to phenomenology for this research and allowed me to focus on the Being relation with the world. Phenomenology addresses the nature of experience from an ontological and 
relationality perspective and is in harmony with my research focus. Hermeneutics is considered to be a form of interpretative study whereby inquiry is guided by the behaviour of the questioner who brings idiosyncratic understandings to a hermeneutic circle of understanding (Heidegger 1962). Hermeneutics is based on the notion of inter-subjectivity: the assumption that human beings share a common world and that this world can be interpreted. A quality of hermeneutics is in the ability to be responsive to emerging themes and relationships. Being responsive was important in my study because of the exploratory and tentative nature of analysis and interpretation.

In the study I sought to explicate and articulate meaning while knowing that the realm of human meaning is complex, dense and not easily grasped. Articulating meaning can best be achieved by interview, thematic analysis and clustering of interview transcripts in a cyclic pursuit of common meanings (Willis 2004). Hence, it was necessary to use a range of phenomenologically-based tools of analysis, interpretation and representation.

In my attempt to uncover what the experience meant to laterlife computer learners, I traversed historical, pedagogical, philosophical, physiological, psychological and sociological domains and attempted to bring these perspectives together. I borrowed from many sources to 'create my own particular interpretative universe' (Eisner 1998: 211). This use of diverse sources is consistent with the qualitative approach, phenomenological foundations and the hermeneutic perspective. The human science method probes and draws from an eclectic array of sources for meaning (van Manen 2002). These sources were inextricably linked to the research questions, methodology and the research design. I also used diverse methods of analysis in an attempt to generate new insights and provide different perspectives 
from a confluent vantage point. I identified four phenomenologically-based analytical and interpretive tools that were used at various times throughout the analysis and interpretative phase. The four tools were: within-case analysis, cross-case analysis, thematic analysis and narrative inquiry.

Data from within-case and cross-case analysis were placed within a thematic framework so that they could be examined and referenced as emerging themes. I used a priori understanding (based on the literature review), emerging understanding (based on field data), and analytical understanding (based on recurring data in crosscase analysis). I made informed choices about meaning and connections between ideas as well as judgments about relevance and significance. 'Exploring emerging themes, being informed by relevant literature and drawing on experience for possible explanations, is part of the developmental process of inquiry and analysis' (Goodfellow 1997: 72). The identification of themes and their meaning can also contribute to narrative analysis. Themes 'disclose the significance of events and this knowledge is used in a dialectical process with the events themselves to determine a best fit plot structure' and therefore have a place in narrative inquiry (Polkinghorne 1988: 19). I constantly examined the narratives as told by the participants in the interviews, comparing them to other stories told by the protagonist and comparing them to stories told by other participants. Narrative schemes pay special attention to the sequence in which actions and events occur and serve as a lens through which seemingly random activities are viewed as related parts of a whole. The capacity of the narrative to draw together, overlay, and expose complex interactions creates a higher order of meaning than otherwise would be possible (Polkinghorne 1988).

This paper is based on my interpretations from this study and is informed by the literature as outlined in the previous section, 'Learning and Being'. 


\section{Ontological and existential influences on the learning Being}

As discussed earlier in the section 'Learning and Being', the Being is viewed as both the self as self (I) and the self as learner (I-learner). Within these two constructs, the self is placed both in relation to the self and in relation to learning, thereby creating important ontological questions that only the self can answer. In my study the participants experienced a variety of ontological imperatives that I will now describe and interpret by using the voices of the participants. These case vignettes will be used to illustrate the threads I identified and explicated from the literature in the process of analysis and interpretation.

In the first part of the 'Learning and Being' section I discussed the notion of disjuncture that precedes the learning experience for adults. One of the participants in the study, Sunny, appears to have experienced this disjuncture and the following vignette describes how this happened. As a voluntary tutor at her local primary school Sunny (aged 78) was regarded as a person with useful and valuable knowledge. She

assisted young children with writing tasks. During a tutoring session a student asked Sunny for assistance on the computer. Sunny admitted she was unable to help and was embarrassed when another child helped.

I decided to come to computer lessons because when I went to the school, I had a third class little one ask me how to underline on the computer. I had no idea. Another third class child came and helped her. Pride I suppose brought me to lessons. 
Publishing on the computer is now an essential part of the writing process for students of all ages and Sunny had no computer skills. She had not expected to need to be proficient in word processing in order to assist young students with writing tasks. She was deeply embarrassed and felt she had let the child down because her job as a volunteer tutor was to assist. The imperative to learn the computer arose from her need to be capable and to be seen as capable and to restore her pride. Her unpleasant experience in a voluntary tutoring capacity triggered Sunny into learning to use the computer. She had previously hand-written an autobiography and was an experienced typist, however, it took an unsettling event to initiate a desire to learn to use the computer. Dewey (1964) refers to this desire as an emotional response to the way things are. Sunny was happy to hand-write the autobiography; however the unsettling event provided the impetus for her to learn how to use a computer. After the event of being unable to assist the child Sunny's inner voice was articulated as 'I have to learn'.

Sunny's experience began with what has been variously termed a trigger event, a disorienting dilemma or a disjuncture (Brookfield 2000). The reflection that stems from disequilibrium is ontologically based and relates to a search for meaning in the event and the realisation that in order to achieve harmony, something has to change (Fromm 1947, Mezirow 1991, 2000a, Brookfield, Jarvis 2001a, 2004, 2005, 2006). In Sartrean terms (the Sartrean inevitability) the only choice Sunny did not have was not to make a choice (Ihde 1990). Sunny could have chosen to no longer engage in voluntary tutoring at the school or to learn how to use the computer. Sunny chose the latter. Her trigger event was sudden, explicit, easily traced and identified. 
However, trigger events may also be a series of events which individually do not have the same effect on the Being as in Sunny's case.

A number of participants admitted that they had wanted to learn to use the computer for some time before beginning lessons.

For quite some time I really wanted to have a go at the computer and just hadn't got around to it.

Pat (aged 68)

I'd wanted to learn the computer for a number of years before I started lessons.

Hilary (aged 77)

I'd been thinking about learning the computer for a little while before I was given one and then I had to go to lessons to learn how to use it.

Aries (aged 72)

This niggling desire felt by Pat, Hilary and Aries is akin to the series of confronting instances described in the literature. The cumulative effect over time of integrating circumstances can provide just as powerful a sense of agency as one trigger event (Tough 1979, Mezirow 2000a). Dewey's (1964) notion of desire arising from a feeling of unease is consistent with both a sudden trigger event and a series of events over a period of time.

Sunny, Pat, Hilary and Aries displayed feelings of 'something is not quite right' and a need to restore equilibrium. Sunny responded to disjuncture almost 
immediately whereas Pat, Hilary, and Aries got on with their lives, put computer learning on the back burner but never let go of their intentionality. The desire to learn and to restore harmony in their lives gave them the confidence that learning would abate the disquiet created by disjuncture. The ontological question of 'How am I going to go about alleviating the disquiet?' was answered by the act of initiating learning and being open to whatever was presented.

In the very early stages of learning to use a computer the older adults in the study found further disjuncture in the terminology and processes used. Far from the disquiet being alleviated they discovered there was more ahead. They experienced what Eliot wrote about, that the way to knowledge is via the path of ignorance and pain. This latest disquiet influenced their self-as-learner constructs and they experienced serious doubts about their ability to learn that unsettled their previously held idea of the self.

Before beginning lessons participants in the study had been observers, not users, of computers and watching younger people effortlessly manipulating the controls had given them a false sense of 'this is going to be easy'. In this study Pat observed her grandchildren clicking effortlessly and thoughtlessly. The seeming ease with which young children manipulated the computer initially gave Pat confidence in her ability to learn. She considered how easy it looked when young people used the computer but how difficult it was when she tried to learn. The events of Pat's disjuncture unfolded as she attempted to maintain her self-confidence and belief in her ability to learn.

I watch my grandchildren on the computer using the Paint program and even the five year old paints pictures and draws all over the screen. They 
say "Oh Nan you just do this, this, this, and this". But I say "It's not that simple." Then they say "Yes it is, you just go click, click, click". I look around and see people who don't look overly bright to me and they can use computers. Anyway, I thought if five year old children can do it, it can't be all that difficult.

Pat's prior experience of typing skills and an expectation that she would have no trouble manipulating the mouse because of observing small children contributed to the construction of her positive self-image as a computer learner. She believed in her own abilities and her self-efficacy was strong. Pat's early self-efficacy began to unravel when she discovered that her original intentions and understandings had not been met. After attending lessons for four weeks she had not reached the level of proficiency she believed she was capable of reaching.

When I started lessons I expected everything to be simple but it's not. It's a slow process and that's been a shock for me. It's slower than I anticipated. I expected to go in and after a few weeks think that I could do a whole lot which I can't.

Pat was initially optimistic about her potential to learn to use the computer and her aspirations were high but she quickly discovered her positive constructions as a computer learner did not match the reality. Pat experienced distress when she was confronted with the disjuncture of her past experiences and the present circumstances. These feelings of self-doubt and inadequacy were all the more poignant because they 'conflicted with what learners felt they ought to accomplish' (Kidd 1973a: 133). Pat 
believed she was not living up to her own expectations and this had a deeper level of distress because of the intrinsic nature of the expectations. She questioned her abilities and her past notion of her self (I) and her self-as-learner (I-learner).

I always considered myself as a fairly smart person but now I don't know.

Pat further described an experience that started out as an amusing exploration on the computer and ended in frustration and confusion that led her to seriously question her ability to learn and the value of continuing lessons.

One day I was just clicking around on the computer, opening various programs and up came 'Links'. I clicked on it and it was a golf game.

Pat found that the instructions on the screen were faulty and in the absence of technical knowledge she was unable to exit from the program. Her dilemma and lack of technical knowledge led her to seek assistance from her daughter.

[When I wanted to finish playing the game] I pressed a button and it kept saying 'Press Start and then end the game' but I couldn't see how I could because it was taking up the whole screen. So I fiddled and kept playing for a little bit and it wasn't getting anywhere so I rang my daughter to ask her what to do. I had no idea what to do and how to get out of the game. 
Pat followed her daughter's instructions and eventually resorted to switching the power off. To Pat's surprise when she turned the computer back on the original screen was restored. When she was given the computer by her son-in-law he had changed the desktop background from fairies to whales.

\begin{abstract}
My daughter told me to press Control, Alt and Delete but that didn't work either so she said "Just turn the whole thing off". When I re-booted the screen went back to the original screen that had been changed by my son-in-law. It came up with fairies instead of whales. I nearly had a stroke. I was absolutely terrified and thought "I can't touch this computer". I [then] thought, "Oh no, I don't think I'll go and have any more computer lessons. I think I'm really past it”.
\end{abstract}

Pat was not only faced with disequilibrium questions but also ontological questions. She questioned the most basic ontological and existential question of 'Who am I?' and confronted the possibility that maybe she was not the person she always thought she was. If learners perceive a heightened sense of disequilibrium instead of an anticipated lessening of unease they may ask 'Why am I doing this?', 'Where is this leading?' and 'Where am I going?' Learning is essentially an ontological process and an existential phenomenon and learners have to reach a resolution in order to restore harmony (Jarvis 2004, 2005, 2006). The laterlife computer learners in this study were repeatedly confronted with both ontological and existential questions as they attempted to reconcile past experience, current experience and their lifeworld. As suggested earlier, the emotional effect of increased tensions and anxiety had a negative effect on self-confidence and self-efficacy in Pat's case. 


\section{Ontological and existential outcomes of learning for the learning}

\section{Being}

The four lifeworld existentials described by van Manen (1997: 101) provide a paradigm for understanding the ontological and existential outcomes of learning. The existentials are lived body (corporeality), lived time (temporality), lived space (spatiality) and lived human relation (relationality or communality). These fundamental existential themes 'pervade the lifeworld of all people' (van Manen) and are compatible with phenomenological themes I identified from participant data. The ontological and existential questions of each of the four existentials and phenomenological themes are: 'What am I?' ('growth and development') 'Who am I?' ('integrity and continuity') 'Where do I belong?' ('positioning and agency') and 'What is important to me?' ('mutualness and value').

\section{Growth and development (corporeality)}

The 'growth and development' phenomenological theme using the existential corporeality is closely linked to the existentials temporality and spatiality. Growth and development occur over time and need energy and desire to enact. The existential questions 'What am I?', 'Who am I?' and 'Where do I belong?' are all interrelated. The question 'What am I?' is asked in relation to time and space 'What am I in time? and 'What am I in space?' Participants in the study were faced with age-related 
changes to their physical and mental Being such as forgetfulness and slowness. Before they were able to continue to grow and develop they accepted where and how they were now in their lives. They used maturity, wisdom and pragmatics to reflect on the tension of self-development versus finitude (Moody 1985) to be able to take control of their actions (locus of control) and to move on (agency) in order to grow and develop. The acceptance was a positive acceptance, not a defeatist acceptance and participants in the study used learning as a means of 'growth and development'.

Implicit in the notion of learning is change and development. The learners in this study faced their limitations and created new opportunities for themselves. They devised new strategies because life was not the same for them. The Being was the same, yet different, and the world had changed, leading to tensions between the private and the public individual. Tennant (1997) believes that this response to a changing world is an essential ongoing dialectical process in which learners are in complete control. I will illustrate this sense of tension, challenge and control as experienced by Quentin (aged 64). Quentin's insight into the self-as-learner revealed a sense of curiosity and a desire to face new situations and overcome obstacles. Despite this self-knowledge and a desire to learn to use the computer, Quentin found that computer terminology created a barrier to his understanding.

I don't have an office background so a lot of the words were new to me. Some of the people seemed to understand them better than me. These were the words in the word processing program. With the computer words, none of us seemed to know what they meant, so the tutor explained them in ordinary language, like, "The icons are the little 
pictures on the screen". This made us all feel more confident that we could learn.

In the following narrative Quentin described a challenging event when he needed to muster courage and determination to control the outcome.

I feel a great sense of satisfaction when I finally manage to do something after running into brick walls. A couple of weeks ago I made an order for an anti-virus program. A special deal that was offered to me because my old one had just expired and I ordered the new one over the net. I was lacking confidence in doing it myself but I thought, "Well, I've got to do it", but I wasn't real sure how to do it. Anyway in the end, I went into it. Half way through it I got into a panic because it asked for my serial number and I couldn't find it. I didn't realise you could switch from one program back to another to find it. I had already given my name and address and bank card number. So as I said, I panicked and then I aborted the whole thing. I switched the computer off. I tried to make a phone call to the help line but they closed at 5pm and this was 8pm. Right, I decided, I have to go through with this, it's not going to get the better of me. So I turned the computer back on and had another go, starting from the beginning again. I entered in all the information for a second time and followed the cues and finally came to the end and saw the word "SUCCESS" flash up. I thought, "Right, well I can do something. Thank goodness, I've learnt something. " 
Quentin was able to confront the complexities of learning in the way that authors (Dewey 1933, Kidd 1973b, Jarvis 1987, 1992, 2001a, 2004, 2005, 2006, Brookfield 2000, Mezirow 2000b) describe because learning is a part of what it is to be human. The risks, frustrations and challenges that Quentin faced were rewarded when he accomplished his goal. His excitement and joy when he saw the word 'SUCCESS' on the screen provided him with the affirmation of self-as-learner he so eagerly sought. His self-as-self reflection as he posed the existential questions of this phenomenological theme, could well be that he was a full human being (having experienced the range of emotions) and a Being in control (he was able to 'push on' and achieve his goal).

Participants in the study may answer the existential question of corporeality, 'What am I?' with the following statements:

I am a full human being. I am a significant Being. I am a Being in control.

\section{Integrity and continuity (temporality)}

The second phenomenological theme of 'integrity and continuity' is grounded in the existential temporality and asks the question 'Who am I?' in relation to time. The question 'Who am I?' can also be asked by other existentials 'Who am I?' in space and 'Who am I?' in relation (to others). Temporality is also closely linked to corporeality because the question of who I am is contingent on what I make of what I am. Participants in the study used reflection to reconfigure and reconstitute time, to 
maintain integrity, and to have a sense of who they were. The participants were aware of time as in the finitude of corporeality but they made the best of it and continued to be themselves using new measures of time. They repositioned themselves in relation to goals to enable growth and development within the time left to them and they looked to the future, beyond their own life (Erikson et al. 1986).

While attending computer lessons Sunny was also writing her family history and local history. Other family members had contributed to these histories and made suggestions. Sunny also has a stake in the future generations beyond her immediate and extended family. As described earlier, she assisted children with spelling and writing at the local primary school. She believed spelling to be very important and a skill she wanted to pass on to future generations. Sunny appeared to have a heightened sense of generativity. The notion of generativity is detailed in the work of Erikson (1950). He believes that in the second last stage of psychosociological development, generativity versus stagnation, there is concern for future generations and life beyond their own. Underlying Erikson's views of psychological and sociological development is the 'time factor'. Time is an important element of the lifeworld of older adults as they seek to 'weigh-up' (i.e. make sense of) and balance the tensions specific to laterlife.

A participant in the study, Aub (aged 86), was writing about his life for posterity, for his daughters and grandchildren. He was also interested in recording the war years and scanning photos and documents so he understood that future generations would look at computers for these things. It was a way of recording things so that they would not get lost or damaged or, like photos, fade over time. Whenever he talked about his life, his children and grandchildren told him to get that down. His niece was also involved in recording the family history and in an interdependent and 
intergenerational way Aub and his niece contributed to the construction of the family and personal history writing.

When I talk about my life in the army and the air force and my life in the bush, my family say "Get it down, get it down". That's when I started to scribble a lot of it. I've got a niece in another country who has some of the family history on disk as a back-up. She emails me.

Sunny and Aub mentioned the generational influence on their decision to write the family history. These examples link to Erikson's (1950) notion of generativity and the concern for future generations. Sunny and Aub looked back to look forward and located the present in the past and the future. Another participant in the study, Coby (aged 82) considered what her grandchildren would be learning in their old age. She wondered what the computer equivalent will be for her grandchildren when they are her age. She projected her experience in empathy to future generations.

There wasn't even the word [computer], when we were children. The word didn't exist let alone the machine. There was no such thing when we were young. This [older adults learning computers for the first time in their lives] can never happen again obviously with computers but we don't know what's going to happen, for something else that's going to be brought in. Some other technical things that they can't learn now so they may have to learn when they're older but it might be easier because they can use a computer. Perhaps it will be easier to learn the next high tech. We have no idea. 
Coby recalled a conversation with her son in which she asked him,

"What do you think the grandson [his son] will do when he's grown up?" He said "We have no idea. It will be something that is not known to us now”. It is almost frightening. Not really, it's progress.

The temporal question 'Who am I?' might be answered by participants in the study by:

I am a Being in a family. I am a Being in history. I am a Being with a story. I am this Being, my Being, ME. I am me. I am the Being I want to be. I am the Being I choose to become. Traces of my Being will live on after I die.

\section{Positioning and agency (spatiality)}

'Positioning and agency' as the third phenomenological theme uses the spatiality existential as a structure to uncover the lived experience of older adult computer learners. This theme is very closely linked to the tensions of age and where participants were now in relation to their lifeworld. The existential question of this theme is 'Where do I belong?' that can also be answered in relation to where they belong in time and where they belong with others. The existential spatiality is also closely linked to the existentials corporeality and temporality, because the 'what' I am 
and the 'who' I am, are significant influences on how and where the Being is placed. Participants in the study were pragmatic and inclined to act with vigour as they railed against a society that positioned them where they did not want to be positioned. They used 'growth and development' and 'integrity and continuity' to strengthen a belief that they could achieve the outcomes they wanted for themselves. The learners in the study did not necessarily accept the position they found themselves in and they decisively set out to enact changes.

Felt space is not just the space occupied by the physical body and it cannot be measured in quantitative ways. Spatiality refers to how the Being experiences the space it is in and the emotional effects of being in a particular place. The place we find ourselves in is referred to in this paper in phenomenological terms as positioning. Participants in this study referred to being on the scrap heap, of being left behind, behind the eight-ball, walked over and treated as little old ladies. These were places and positions they did not want to occupy but they felt they occupied these undesirable spaces because of the way they were treated. The older adults in this study believed they were treated differently because of their age. They also believed they were marginalised. Participants in this study perceived a distance between what was wanted and what was attainable from the position they were in.

When Alex (aged 73) retired from work she found she was treated differently in ways that made her angry. She decided the computer skills she learnt could be applied to creating a professional look in dealings with the medical profession, government agencies and in local interest groups. Alex had a need to learn the computer for self-affirmation and affirmation by the community. In order to maintain integrity and continue the Being narrative, Alex found she had to find a way to re- 
position herself, from a retiree with no work title, to a professional person of intellect and capability.

I think it's very important to have computer skills to be treated as a professional because once you're out of the workforce you've got very little to fall back on. You are assessed on your presentation of written material. If you can do it like they do it today, like the modern people in the workforce, then you've achieved something. You're treated differently.

Inherent in positioning is the perceived ability to act to change positions. In order to re-position themselves to a space they wanted to occupy the participants needed a sense of agency i.e. the ability to act. Lived space as felt space can make action (sense of agency) easier or more difficult. It can make the distance between the current position and the preferred positions appear closer or further away. Spatiality is an important aspect for older adults. Their bodies, the outward symbol of their age, are evident for all to see and affect how they experience the body-in-space.

The sense of agency for the participants was the perceived ability to move off the scrap heap into the mainstream and to move out of the corner at family gatherings, into the centre of discussions. However, without the parlance of the computer-world i.e. the modern world, older adults in this study could not participate in their lifeworld from other than a peripheral position. They were afraid to participate in discussions relating to computers because they believed they would be dismissed as silly and ignorant. The older adults in the study had a need be treated in their lifeworld by others in ways that affirmed and confirmed their position. When Quentin retired he 
realised that everything around him hinged on computers and that he was being left further and further behind. As his knowledge of computers developed from the lessons and his confidence in using computers increased, he found he was better able to understand his lifeworld.

The computer has opened up a whole new area of life for me. Instead of feeling as though I am almost ready for the scrap heap I am able to understand life around me more in this modern age when technology is moving ahead so fast.

Bobby (aged 70) also believed that the world was less strange as a result of attending computer lessons and gaining a greater understanding of how they work.

\section{I understand things now.}

The sense of felt space and the meaning for the older adults in the study created a fertile impetus for learning and continued learning. The learners aspired to be treated the same as they had been throughout their lives. They wanted to legitimately claim a place in a shared space with people of all ages and professions and they saw learning to use the computer as a vehicle to achieve this. Everyday life since retirement meant being positioned separately in their lifeworld and they did not want to be marginalised, feel powerless, or insignificant. They challenged the scrap heap situation and decided to do something about it so that they could experience felt space in self-determined ways. If the self becomes the space it is in (van Manen 1997) then 
laterlife computer learners in the study were positioning themselves in positive and life-affirming places.

Participants in the study might answer the spatiality question 'Where do I belong?' with one of the following statements:

I belong where I belong. I belong where I can be myself. I belong where I am important for my Being. I belong where my Being is authenticated.

\section{Mutualness and value (relationality)}

The existential relationality is used to develop the phenomenological theme of 'mutualness and value' and asks the questions 'What is important to me?' and 'Who do I want to be with?' Relationality is a mirror image of spatiality because positioning always means positioning in relation to others. With a heightened sense of time the older adults in the study sought to find meaning in their lives and they looked to a sense of communality for answers. Participants looked beyond individual needs to find mutualness and value in their lifeworld. They wanted a sense of belongingness, of mutual and moral obligation and value in relationships. Participants took responsibility for sharing and contributing and participating for the greater good, for the good of both the self and others. This decision may be another opportunity to reach out to others and in doing so realise their humanity (Brookfield 1986). The 'mutualness and value' theme is also closely linked to Kidd's (1973b) notion of Being-becoming-belonging. 
In the previous section I discussed the phenomenological spatial theme of 'positioning and agency' and the need for older adults to participate meaningfully in their lifeworld by placing the self in a position of choice that reflects who they are and where they want to be. It is human to look for a role in life, a place to call our own, and this always involves other people. People seek recognition as a social being and want to establish a place that is their own. Participants in the study wanted to be placed in authentic and life-affirming spaces. They did not want to be patronised or (in the case of the females) to be treated as 'little old ladies'. They wanted relationships that were meaningful and relevant. They challenged marginalisation and re-placed themselves in spaces where relationships and discourses allowed them to be included, not excluded.

One form of mutuality in this study related to participants looking at the present from the past and the future. Participants were acutely aware that the door to the future would not open for them. Hence, their generativity concerns implied mutuality. Learning to use the computer created opportunities for the younger generation to assist and support the parents and grandparents. Children and grandchildren were giving back the mutuality of the lifeworld, for the nurturing and sustenance their parents gave them as children. It was an opportunity in life to provide something of value, something that would contribute to a better quality of life for the parents and grandparents. In this study there were many instances of children and grandchildren assisting parents and grandparents with technical problems and emotional support and encouragement. Clem (aged 81) described many instances when her son, daughter-in-law and grandchildren assisted and encouraged her, financially and emotionally. 
The whole family said I would be able to handle the computer. Everyone has encouraged me to the nth degree. They've not tolerated any feelings of failure on my part. They say "Come on, you can do it". Anyway I don't mind.

Pat mentioned her daughter and her son-in-law a number of times throughout the interview in relation to advice that provided her with reassurance and emotional support. From the beginning Pat's son-in-law provided her with support and reassurance, anticipating and addressing her fears. She was terrified of the computer and everything about it but her son-in-law helped her overcome this fear.

I was absolutely terrified of the computer. But my son-in-law wrote me a note. It said "You cannot damage this computer. It has been trained for use by impatient children".

Coby's family provided her with emotional support and encouragement and checked on her progress.

My younger son in London says he thinks I've learnt quite quickly. He congratulates me and he's nice about it. I think he says it to butter me up and to do my ego good but why not, it's always nice to get buttered up. I telephone my son and daughter overseas once a fortnight because I like to hear their voices. They will sometimes say to me "We haven't had any email from you for a long time, how are you going on the computer? 
Despite there being much evidence in this study of increased and enhanced relationships between the generations there was also potential for disconnection and detachment with children and grandchildren. Morgan (aged 82) couldn't understand a word they said. Morgan stated that she would not ask her children or grandchildren any questions about computers because that would be a waste of time.

My grandchildren and family adults are of no help. They can't explain stuff to a learner. They can do it but they can't teach me how to do it. I've tried to learn with the family but it's hopeless. I've given up on them. They don't have the skills of transmission and I finish up the loser. If I'm quick enough I may get it but with my limited experience it's hopeless. It's just a quick fix. There's no teaching going on. I'd rather hammer away by myself, because that's where I get answers. Sooner or later.

There was also the potential for disconnection with friends who were not interested in computers and computer-related conversations. Learning the computer for older adults has the potential for loss of relationships with same-age friends and this links to the notion of the Sartrean inevitability.

Sunny suggested that raising the conversation about attending computer classes may be seen as big-noting and she did not want to be alienated from her friends.

Amongst my private friends, some of them say "I'd never learn computers". It's not that they couldn't but they wouldn't apply 
themselves. None of my friends are interested in conversations about computers. They say “Don't talk computers to me”. It doesn't matter there's other things to talk about. I don't feel that I should say "I went to computer class" because people are not interested in that conversation.

Morgan's friends were also opposed to computers, and computer conversations went down like a lead balloon.

I have friends who will just drop dead if you mention computer. They have a computer in the home and I know they are connected up because I checked it with their husbands but I despair of ever getting them to write me one sentence in return email. I'd say I could forget about that.

Morgan recently moved to Sydney having lived interstate for many years and the friends she referred to were long-standing. If Morgan chooses in the future to only use email to communicate with these friends there is a possibility that no communication between them will take place. It also appeared to be a very sensitive issue. Morgan was emotionally affected by the stubbornness of her friends and the impact this had on the friendship and the potential for loss of friendship in the future. If, as in Sunny's case, they are able to maintain the relationship with a strong base from shared pursuits and past experiences there may be no threat to the friendship. If Morgan and Sunny take to the new pursuit with vigour and gravitate to new people interested in computers they may believe they have nothing in common anymore with past friends. 
In fact Jarvis (2001b: 202) believes that learning can have 'unforeseen consequences' and 'lead to fragmentation in society'. The view that older adult computer interest has the potential to divide the older adult population is shared by Coby. She suggested that older adults were polarised over the issue of owning and using computers.

I think in general people my age talk about computers. I don't know of anyone who's learning like I am but I think most older people are either absolutely adamant that they're not going to do it and they couldn't be bothered and have no desire to use it or they are competent and know what they are doing.

Coby believed that conversations about computers were common and that most people her age at least talked about the topic. However, she also stated that in her experience older people fell into one of two camps, either they were vehemently opposed to using computers or they were capable computer users who were comfortable with the technology.

The learning experiences of the participants in the study were not just one person's learning experience. They encompassed family, friends, neighbours and the community. The learning experiences were a social phenomenon in which both the individual and the society benefited (Tough 1979, Jarvis 1987, Mezirow 1991, Beatty and Wolf 1996, Findsen 2005). Participants in this study described instances of mutual obligation, belongingness, sharing and support.

The laterlife computer learners in the study valued close family relationships and sought to strengthen these bonds. They negotiated their position in a changing world and were excited by the opportunity that learning the computer gave them to be 
a part of the lives of all generations within the family. They placed importance on having strong and stable relationships where they were grounded in their place within their lifeworld.

The existential and ontological questions of relationality (What is important to me? Who do I want to be with?) may be answered by participants in this study by one of the following statements:

I am a valued Being within my relations. I am able to give and receive. I have relations that affirm me as a same and a separate Being.

\section{Concluding remarks}

The laterlife computer learners in the study viewed computer learning as a path to self-actualisation and also as a way of being able to represent the self in authentic ways. Participants wanted connectedness with others and depth in their lives. They valued relationships and feeling a part of the world and sought unity with the self and others. It is human to want to have something to think about: to get dressed up to go somewhere; to do things that are meaningful and fulfilling. Humans do not want to face the nothingness. They want to have depth to their lives and they want to feel useful and valued. The people in the study sought compatibility between thoughts and actions (sense of agency) and beliefs and emotions (relationships). The notion of the Being as an entity that is becoming (growing and developing) and belonging (with others) was an important aspect of the study. Participants were being, becoming and belonging in the pursuit of the existential self. They pursued opportunities to be 
authentic and to have the authentic Being actualised. They looked for ways to use the computer that were relevant in their lifeworld and that would reflect the authentic self.

In the section Learning and Being I investigated the view of many authors that adult learning is basically existential, the search for the authentic self, and ontological, the search for meaning in being. In my study of laterlife computer learners, I interpreted many aspects of the learning experience as being of an existential and ontological nature. At times it was difficult to differentiate between the two perspectives, existential and ontological. They appear to be inexplicably intertwined and hence provided a richer understanding of the adult learning experience. The lived experience of the learners in the study provoked both existential and ontological questions that demanded answers. Their voices provided stark and revealing insights into the learning experience that enabled me to identify phenomenological threads. While I acknowledge that the interpretations I have made relate to laterlife computer learners, I believe there is sufficient commonality with other adult learning that may be informed by my study.

\section{Acknowledgements}

I am indebted to the laterlife computer learners who took part in my research and trusted me with their stories. I thank my PhD supervisor, Dr Sandy Schuck for her interest and encouragement throughout the many phases of the research journey. I acknowledge the support and financial assistance given to me by the University of Technology Sydney for the period 2002-2005 that enabled me to undertake the research. I further appreciate and value the vital guidance given in the writing of this paper by a colleague and critical friend, Ros Brennan Kemmis. This paper has been 
written with the support and time provided by Charles Sturt University, Wagga Wagga, Australia.

\section{References}

Allport, G. (1955). Becoming. New Haven: Yale University Press.

Beatty, P. T., and Wolf, M. A. (1996). Connecting with older adults: Educational responses and approaches. Malabar, FL: Krieger Publishing.

Boud, D., Keough, R., and Walker, D. (Eds.). (1985). Reflection: Turning experience into learning. London: Kogan Page.

Brookfield, S. D. (1986). Understanding and facilitating adult learning: A comprehensive analysis of principles and effective practices. San Francisco: Jossey-Bass.

Brookfield, S. D. (2000). Adult cognition as a dimension of lifelong learning. In J. Field \& M. Leicester (Eds.), Lifelong learning: Education across the lifespan (pp. 89-101). London: RoutledgeFarmer.

Cell, E. (1984). Learning to learn from experience. Albany: State University of New York Press.

Day, M. J. (1988). Educational advising and brokering: The ethics of choice. In R. G. Brockett (Ed.), Ethical issues in adult education. New York: Teachers College Press.

Dewey, J. (1933). How we think (1998 ed.). Boston: Houghton Mifflin.

Dewey, J. (1964). John Dewey on education: Selected writings (1974 ed.). Chicago: The University of Chicago Press. 
Eisner, E. W. (1998). The enlightened eye: Qualitative inquiry and the enhancement of educational practice. Upper Saddle River, NJ: Prentice-Hall.

Eliot, T. S. (1969). The complete poems and plays of TS Eliot. London: Faber and Faber.

Erikson, E. H. (1950). Childhood and society. New York: Norton.

Erikson, E. H., Erikson, J. M., and Kivnick, H. Q. (1986). Vital involvement in old age. New York: W. W. Norton.

Findsen, B. (2005). Learning later. Malabar, FL: Krieger.

Frankl, V. E. (1984). Man's search for meaning. New York: Washington Square Press.

Fromm, E. (1947). Man for himself. London: Routledge.

Goodfellow, J. (1997). Narrative inquiry: Musings, methodology and merits. In J.

Higgs (Ed.), Qualitative research: Discourse on methodologies (pp. 61-74).

Sydney: Hampden Press.

Heidegger, M. (1962). Being and Time (J. Macquarie \& E. Robinson, Trans.). Oxford: Blackwell.

Ihde, D. (1990). Technology and the lifeworld: From garden to earth. Bloomington: Indiana University Press.

Jarvis, P. (1987). Adult learning in the social context. New York: Croom Helm.

Jarvis, P. (1992). Paradoxes of learning: On becoming an individual in society. San Francisco: Jossey-Bass.

Jarvis, P. (2001a). Learning in laterlife: An introduction for educators \& carers. London: Kogan Page. 
Jarvis, P. (2001b). Questioning the learning society. In P. Jarvis (Ed.), The age of learning: Education and the knowledge society (pp. 194-204). London: Kogan Page.

Jarvis, P. (2004). Adult education and lifelong learning ( $3^{\text {rd }}$ ed.). London: RoutledgeFalmer.

Jarvis, P. (2005). Towards a philosophy of human learning: An existentialist perspective. In P. Jarvis \& S. Parker (Eds.) Human learning: A holistic approach (pp. 1-15). London: Routledge.

Jarvis, P. (2006). Towards a comprehensive theory of human learning. London: Routledge.

Keating, D. P., and Maclean, D. J. (1988). Reconstruction in cognitive development: A post-structuralist agenda. In P. B. Baltes, D. L. Featherman \& R. M. Lerner (Eds.), Life-span development and behavior (Vol. 8, pp. 283-317). Hillsdale, NJ: Lawrence Erlbaum.

Kidd, J. R. (1973a). How adults learn (2 ${ }^{\text {nd }}$ ed.). New York: Cambridge.

Kidd, J. R. (1973b). Relentless verity: Education for being-becoming-belonging. Syracuse, NY: Syracuse University.

Kolb, D. (1984). Experiential learning. Englewood Cliffs, NJ: Prentice Hall.

Maslow, A. (1962). Toward a psychology of being. Princeton: Van Nostrand Press.

Maslow, A. H. (1970). Motivation and personality (2 ${ }^{\text {nd }}$ ed.). New York: Harper and Row.

Mezirow, J. (1991). Transformative dimensions of adult learning. San Francisco: Jossey-Bass. 
Mezirow, J. (2000a). Learning to think like an adult: Core concepts of transformation theory. In J. Mezirow (Ed.), Learning as transformation: Critical perspectives on a theory in progress (pp. 4-51). San Francisco: Jossey-Bass.

Mezirow, J. (Ed.). (2000b). Learning as transformation: Critical perspectives on a theory in progress. San Francisco: Jossey-Bass.

Moody, H. R. (1976). Philosophical presuppositions of education for old age. Educational Gerontology, 1, 1-16.

Moody, H. R. (1985). Philosophy of education for older adults. In D. B. Lumsden (Ed.), The older adult as learner: Aspects of educational gerontology (pp. 2549). Washington, DC: Hemisphere.

Polkinghorne, D. E. (1988). Narrative knowing and the human sciences. Albany, NY: State University of New York Press.

Rogers, C. R. (1951). Client centered therapy. Boston: Houghton Mifflin.

Rogers, C. R. (1969). Freedom to learn. Columbus: Merrill.

Sherron, R. H., \& Lumsden, D. B. (Eds.). (1990). Introduction to educational gerontology ( $3^{\text {rd }}$ ed.). New York: Hemisphere.

Stanage, S. M. (1987). Adult education and phenomenological research: New directions for theory, practice, and research. Malabar, FL: Robert E. Krieger. Tennant, M. (1997). Psychology and adult learning ( $2^{\text {nd }}$ ed.). London: Routledge.

Thorson, J. A. (2000). Aging in a changing society (2 ${ }^{\text {nd }}$ ed.). Philadelphia: Brunner/Mazel.

Tough, A. (1979). The adult's learning projects ( $2^{\text {nd }}$ ed.). Toronto: Ontario Institute for Studies in Adult Education.

van Manen, M. (1997). Researching lived experience: Human science for an action sensitive pedagogy ( $2^{\text {nd }}$ ed.). Ontario: The Althouse Press. 
Willis, P. (2004). From "The things themselves" to a "Feeling of understanding": Finding different voices in phenomenological research. The Indo-Pacific Journal of Phenomenology, 4(1), 1-13. 